\title{
Persister Cells Resuscitate via Ribosome Modification by 23S rRNA Pseudouridine Synthase RluD
}

\author{
Sooyeon Song and Thomas K. Wood* \\ Department of Chemical Engineering, Pennsylvania State University, \\ University Park, Pennsylvania, 16802-4400, USA
}

*For correspondence. E-mail tuw14@psu.edu

Tel. (+)1 814-863-4811; Fax (1) 814-865-7846

Running title: Persisters resuscitate via ribosome modification through RluD.

Keywords: persisters, ribosomes, dormancy 


\begin{abstract}
Upon a wide range of stress conditions (e.g., nutrient, antibiotic, oxidative), a subpopulation of bacterial cells known as persisters survive by halting metabolism. These cells resuscitate rapidly to reconstitute infections once the stress is removed and nutrients are provided. However, how these

5 dormant cells resuscitate is not understood well but involves reactivating ribosomes. By screening 10,000 compounds directly for stimulating Escherichia coli persister cell resuscitation, we identified that 2-\{[2(4-bromophenyl)-2-oxoethyl]thio \}-3-ethyl-5,6,7,8-tetrahydro[1]benzothieno[2,3-d]pyrimidin-4(3H)-one (BPOET) stimulates resuscitation. Critically, by screening 4,267 E. coli proteins, we determined that BPOET activates hibernating ribosomes via $23 \mathrm{~S}$ rRNA pseudouridine synthase RluD, which increases

10 ribosome activity. Corroborating the increased waking with RluD, production of RluD increased the number of active ribosomes in persister cells. Also, inactivating the small RNA RybB which represses rluD led to faster persister resuscitation. Hence, persister cells resuscitate via activation of RluD.
\end{abstract}




\section{INTRODUCTION}

Upon myriad stresses such as antibiotic stress, a sub-population of bacterial cells becomes dormant and multi-stress tolerant $(1,2)$; these cells are known as persisters. The persister phenotype is not due to genetic change, since upon re-growth, persisters cells behave the same as the original culture. Persistence is relevant in the environment since almost all cells face starvation (3) and relevant in medicine since recurring infections may be the result of regrowth of persister cells (4). The persister sub-population should be distinguished from slow-growing cells such as those in the stationary-phase or those generated by nutrient shifts (5); these slow-growing cells may be distinguished from persisters since the whole population of slow-growing cells are tolerant to antimicrobials whereas the non-growing persister population is a small sub-population (less than 1\%) (6). This distinction is critical since tolerant cells utilize alternate sigma factors like RpoS in Escherichia coli to redirect gene expression as an active response against stress (7), whereas persisters cease responding and become dormant $(5,8)$.

To treat persister cell infections, it is important to understand how they form and how they resuscitate. The prevailing view for their formation (6) is that to reduce metabolism, cells activate toxins of toxin/antitoxin (TA) systems (9). The best genetic evidence for this is that deletion of toxins MqsR (10, 11), TisB (12), and YafQ (13) decreases persistence. Moreover, production of non-TAs toxins also increases persistence (14). However, since nutrient deprivation also results in persistence (15), the subpopulation of cells may become dormant simply by running out of food. In addition, we have proposed a model whereby the alarmone ppGpp (synthesized as a result of myriad stress conditions), directly creates persister cells via ribosome dimerization, without the need of TA systems (16). Regardless of the mechanism, persistence appears to be an elegantly-regulated response to an unfavorable environment (17).

In regard to resuscitating persister cells, little has been determined about the mechanism. It has been suggested that persister cells resuscitate by inactivating toxins such as TacT acetyltransferase via peptidyl-tRNA hydrolase Pth (18), but this has not been demonstrated. It is established that persister cells revive in response primarily to environmental signals, such as fresh nutrients (rather than stochastically) 
(19). In addition, persisters revive in an heterogeneous manner, by activating ribosomes; cells increase their ribosome content until a threshold is reached, then they begin to elongate or divide (19). For resuscitation, the persisters sense nutrients by chemotaxis and phosphotransferase membrane proteins, reduce cAMP levels to rescue stalled ribosomes, unhybridize $100 \mathrm{~S}$ ribosomes via HflX, and undergo chemotaxis toward fresh nutrients (20).

In the present study, to discern additional insights into how ribosomes are active as persister cells resuscitate, we converted the complete $E$. coli population into persister cells so that we could screen for the first time compounds that enhance persister resuscitation. From a 10,000 compound library, we identified that 2-\{[2-(4-bromophenyl)-2-oxoethyl]thio\}-3-ethyl-5,6,7,8-tetrahydro[1]benzothieno[2,3d]pyrimidin-4(3H)-one (BPOET) stimulates persister cell waking. Critically, we determined that the

50 mechanism by which BPOET resuscitates persisters is via activation of the 23S rRNA pseudouridine synthase RluD, which is important for ribosome activity. Hence, BPOET stimulates persister resuscitation by activating ribosomes via RluD.

\section{MATERIALS AND METHODS}

Bacteria and growth conditions. E. coli K-12 and its isogenic mutants (Table 1) were grown routinely

55 in lysogeny broth (21) (22) at $37^{\circ} \mathrm{C}$. BPOET was obtained from ChemBridge (San Diego, CA).

Persister cells. E. coli persister cells were generated $(19,23)$ by treating exponentially-growing cells (turbidity of 0.8 at $600 \mathrm{~nm}$ ) with rifampicin $(100 \mu \mathrm{g} / \mathrm{mL})$ for 30 min to stop transcription, centrifuging, and adding LB with ampicillin $(100 \mu \mathrm{g} / \mathrm{mL})$ for $3 \mathrm{~h}$ to lyse any non-persister cells. Cells pellets were washed twice with $0.85 \% \mathrm{NaCl}$ then re-suspended in $0.85 \% \mathrm{NaCl}$.

60 ChemBridge screen to identify resuscitation compounds. To identify compounds that resuscitate $E$. coli persister cells, the DIVERset Library from ChemBridge (San Diego, CA) containing 10,000 druglike compounds with high pharmacophore diversity was evaluated by adding $4 \mu \mathrm{L}$ of each compound (final concentration $100 \mu \mathrm{M}$, dissolved in DMSO) to $186 \mu \mathrm{L}$ of LB in 96 well plates and then adding $10 \mu \mathrm{L}$ of persister cells. The negative control was 2 vol\% DMSO. Resuscitation was calculated as the change in 
65 turbidity at $600 \mathrm{~nm}$. The compounds that were identified initially were re-tested in M9 minimal medium with $5 \mathrm{X}$ alanine (24).

Pooled ASKA screen to identify resuscitation proteins. To identify proteins responsible for resuscitation, all 4,267 ASKA clones (GFP-) (25) were combined, grown to a turbidity of 2 at $600 \mathrm{~nm}$ in LB medium, and their plasmids isolated using a plasmid DNA Mini Kit I (OMEGA Bio-Tek, Inc., Norcross, GA, USA). The pooled ASKA plasmids ( $1 \mu \mathrm{L}$ containing 30 ng DNA) were electroporated into $50 \mu \mathrm{L}$ of $E$. coli BW25113 competent cells, $1 \mathrm{~mL} \mathrm{LB}$ medium was added, and the cells were grown to a turbidity of 0.5 at $600 \mathrm{~nm}$. Chloramphenicol was added $(30 \mu \mathrm{g} / \mathrm{mL})$ to the culture to maintain the plasmids, and the cells were incubated at $250 \mathrm{rpm}$ to a turbidity of 0.8 . Rifampicin followed by ampicillin was added to make persister cells, then the persister cells were washed twice with 1x PBS buffer, contacted with $100 \mu \mathrm{M}$ BPOET for $2 \mathrm{~h}$ in M9 medium that lacked a carbons source, and plated on LB (Cm) agar plates. Faster colony appearance indicated faster persister resuscitation. Plasmids were isolated from the colonies and sequenced using primer pCA24N_F: GCCCTTTCGTCTTCACCTCG.

Single-cell persister resuscitation. As described previously (19), $5 \mu \mathrm{L}$ of cell populations consisting of $100 \%$ persister cells were added to $1.5 \%$ agarose gel pads containing either M9 medium with glucose $(0.4$ $\mathrm{wt} \%$ ) or alanine $(5 \mathrm{X})$ as a carbon source (24), and resuscitation was monitored at $37^{\circ} \mathrm{C}$ via a light microscope (Zeiss Axio Scope.A1, bl_ph channel at 1000 ms exposure).

Active 70S ribosome assay. The GFP signal of resuscitating persisters of E. coli K-12 MG1655ASVGFP (26) with RluD was monitored using a fluorescence microscope (Zeiss Axioscope.A1, bl_ph channel at 1,000 ms exposure and GFP channel at 10,000 ms exposure). E. coli K-12 MG1655-ASVGFP 85 produces an unstable variant of GFP (half-life less than $1 \mathrm{~h}$ ) under the control of the 16S rRNA ribosomal promoter $r r n b \mathrm{P} 1(26)$. 


\section{RESULTS \& DISCUSSION}

BPOET resuscitates $E$. coli persister cells. To identify compounds that resuscitate E. coli persister cells, we first increased by $10^{5}$-fold the persister cell population by pre-treating with rifampicin to cease metabolism by stopping transcription followed by ampicillin treatment to kill any remaining non-persister cells (23). In this way, nearly $100 \%$ of bacterial cell population was converted into persister cells. Hence, we were able to both screen for compounds that more rapidly resuscitate persister cells as well as confirm our hypotheses via single-cell microscopy. The persister cells generated in this way have been (i) confirmed eight ways (19), (ii) used to determine that persister cells wake via ribosome activation (19)

95 and chemotaxis (20), (iii) used to show that the cells capable of resuscitation in a viable but not culturable population are equivalent to persister cells (15), (iv) used to identify compounds that kill persister cells (27), and (v) used to show that the alarmone ppGpp directly creates persister cells by stimulating ribosome dimerization (16). In addition, our method to generate a high population of persister cells has been utilized by at least six independent groups (28-33).

$100 \quad$ Using 96-well plates, the persister cells $(10 \mu \mathrm{L})$ were added to $190 \mu \mathrm{L}$ of $\mathrm{LB}$ containing one each of the 10,000 compounds of the DiverSet library dissolved in dimethyl sulfoxide $(100 \mu \mathrm{M}$ final concentration), and growth was monitored via the change in turbidity for up to $48 \mathrm{~h}$. Starting at a turbidity of 0.05 , a 140-fold increase in growth was possible (maximum final turbidity of 0.69). Table 1 shows the 27 compounds that were identified that stimulated persister cell resuscitation relative to the negative control of dimethyl sulfoxide. Upon confirming the results of these initial hits in minimal alanine medium, we found BPOET $(100 \mu \mathrm{M})$ was most effective and increased persister cell waking by 44 -fold in 96-well plates based on the increases in turbidity as well as found that BPOET increases the waking of single persister cells by 4-fold (Figure 1, Table S1). Hence, we focused on this compound.

BPOET resuscitates $E$. coli persister cells by modifying ribosomes. To determine how BPOET

110 resuscitates persister cells, we pooled the 4,267 ASKA clones in which each E. coli protein is produced from plasmid pCA24N, produced persister cells carrying these plasmids, contacted with $100 \mu \mathrm{M}$ BPOET, plated the cells, and chose the largest colonies that formed on LB plates. Our rationale was that any 
pathway stimulated by BPOET would be even more active if the number of rate-limiting proteins in that pathway were increased, and cells that wake first would form colonies faster.

115 Using this approach, we identified five proteins whose production increased resuscitation: RluD, YjiK, SrlR, Smf, and YeeZ. These proteins are related to contacting with BPOET since addition of the diluent DMSO alone and sequencing larger colonies did not identify these five proteins but instead identified TmcA, a tRNA ${ }^{\text {Met }}$ cytidine acetyltransferase, which is a general factor required for translation that likely led to larger colony sizes with the diluent. Of the proteins related to BPOET, only RluD (23S rRNA 120 pseudouridine synthase) and SrlR (represses the gut operon for glucitol metabolism) have been characterized; we focused on RluD because it is related to ribosomes, and we have shown inactivating ribosomes causes persistence (23) and activating ribosomes resuscitates persister cells $(16,19,20)$. RluD is involved in the synthesis and assembly of $70 \mathrm{~S}$ ribosomes as well as their function based on its posttranscriptional modification of $23 \mathrm{~S}$ rRNA to form three pseudouridine (5-ribosyl-uracil) nucelosides at 125 positions 1911, 1915, and 1917 (34). In pseudouridine, uracil is attached via a carbon-carbon bond to the sugar base rather than through a carbon-nitrogen bond. The $23 \mathrm{~S}$ rRNA pseudouridines increase the stability of the tertiary structure of $23 \mathrm{~S}$ rRNA and are located in a stem loop structure that is involved in peptidyltransferase and interacts with mRNA, tRNA, 16S rRNA, and ribosome release factor. Hence, $\mathrm{RluD}$ is responsible for efficient ribosome function (34).

130 RluD enhances persister cell resuscitation. To explore further the role of RluD and persister resuscitation, we utilized single cell studies since persister cells are heterogeneous (19) and wake with different frequencies (which would be missed if we monitored planktonic populations). We found that deleting rulD reduces the frequency of single-cell persister resuscitation dramatically (11-fold) compared to the isogenic wild-type strain on minimal glucose agarose gel pads (Fig. 1A, Table S1, Fig. S1). In 135 addition, no colonies were found on M9 glucose agar plates after inactivating RluD (Fig S2), confirming that persister cells are severely challenged in resuscitation without RluD. Corroborating these two results with the $r l u D$ mutant, production of RluD increased the frequency of waking by 11 -fold on glucose medium (Fig. 1A, Table S1, Fig S1) and increased waking on rich medium (results not shown). In 
addition, the $r l u D$ deletion has no effect on persister cell formation (Fig S2). Therefore, RluD stimulates persister cell resuscitation but does not affect persister formation.

RluD increases active ribosomes for resuscitation. Using a GFP reporter that indicates the number of 70S ribosomes in individual persister cells (19), we found that producing RluD before making persister cells makes $85 \pm 6 \%$ of the cells have high ribosome fractions compared to not producing RluD (Fig. 1B). The GFP reporter indicates transcription of $r r s B$ (16S rRNA), $g l t T$ (tRNA-glu), $r r l B$ (23S rRNA) and $r r f B$

145 (5S rRNA); hence, it indicates production of the three major rRNA building blocks. Although this is not a direct observation of $70 \mathrm{~S}$ ribosomes, this method is a suitable proxy for the number of ribosomes based on measurement of rRNA concentrations and has been used frequently $(19,35-37)$, and we have verified its use by isolating ribosomes and comparing GFP fluorescence (19). Hence, the increased persister cell resuscitation with RluD is directly due to the increase in active (70S) ribosomes of persister cells.

150 RybB antagonizes persister cell resuscitation. Since the small RNA RybB represses RluD (38), we investigated its impact on persister resuscitation. As expected, we found that deletion of $r y b B$ increases the frequency of persister cell waking by 8 -fold (Fig. 1A, Table S1, Fig. S1).

In summary, the results presented here demonstrate that ribosomes may be activated for specific cell cycles such as recovery from dormancy. Specifically, by screening for compounds for the first time that enhance persister cell resuscitation, we have (i) determined that ribosomes are modified by RluD as cells resuscitate and resume ribosome activity, (ii) identified a novel compound, BPOET, that activates persister cells, and (iii) linked small RNAs to persistence. Hence, these results extend our understanding of how persister cells are activated which has a far-reaching impact in that all bacteria cope with nutrient stress and become dormant.

\section{ACKNOWLEDGEMENTS}

This work was supported by funds derived from the Biotechnology Endowed Professorship at the Pennsylvania State University. We are grateful for the $r y b B$ mutant provided by Dr. Gisela Storz. The authors have no conflicts of interest. 


\section{REFERENCES}

1. Hobby GL, Meyer K, \& Chaffee E Observations on the mechanism of action of penicillin. P Soc Exp Biol Med 50:281-285 (1942).

2. Bigger JW Treatment of staphylococcal infections with penicillin - By intermittent sterilisation. Lancet 2:497-500 (1944).

3. Song S \& Wood TK Post-segregational Killing and Phage Inhibition Are Not Mediated by Cell Death Through Toxin/Antitoxin Systems. Front Microbiol 9:814 (2018).

4. Van den Bergh B, Fauvart M, \& Michiels J Formation, physiology, ecology, evolution and clinical importance of bacterial persisters. FEMS MIcrobiol. Rev. 41:219-251 (2017).

5. Kim J-S \& Wood TK Tolerant, Growing Cells from Nutrient Shifts Are Not Persister Cells. mBio 8:e00354-00317 (2017).

6. Ronneau S \& Helaine S Clarifying the Link between Toxin-Antitoxin Modules and Bacterial Persistence. J. Mol. Biol. (2019).

7. Wang X, et al. Antitoxin MqsA helps mediate the bacterial general stress response. Nature Chem. Biol. 7:359-366 (2011).

8. Kim J-S \& Wood TK Persistent Persister Misperceptions. Front. Microbiol. 7:2134 (2016).

9. Wang X \& Wood TK Toxin-antitoxin systems influence biofilm and persister cell formation and the general stress response. Appl. Environ. Microbiol. 77:5577-5583 (2011).

10. Kim Y \& Wood TK Toxins Hha and CspD and small RNA regulator Hfq are involved in persister cell formation through MqsR in Escherichia coli. Biochem. Biophys. Res. Commun. 391:209-213 (2010).

11. Luidalepp H, Jõers A, Kaldalu N, \& Tenson T Age of Inoculum Strongly Influences Persister Frequency and Can Mask Effects of Mutations Implicated in Altered Persistence. J. Bacteriol. 193:3598-3605 (2011).

12. Dörr T, Vulić M, \& Lewis K Ciprofloxacin causes persister formation by inducing the TisB toxin in Escherichia coli. PLoS Biol. 8:e1000317 (2010).

13. Harrison JJ, et al. The chromosomal toxin gene yafQ is a determinant of multidrug tolerance for Escherichia coli growing in a biofilm. Antimicrob. Agents Chemother. 53:2253-2258 (2009).

14. Chowdhury N, Kwan BW, \& Wood TK Persistence Increases in the Absence of the Alarmone Guanosine Tetraphosphate by Reducing Cell Growth. Scientific Reports 6:20519 (2016).

15. Kim J-S, Chowdhury N, Yamasaki R, \& Wood TK Viable But Non-Culturable and Persistence Describe the Same Bacterial Stress State. Environ Microbiol 20:2038-2048 (2018).

16. Song S \& Wood TK ppGpp Ribosome Dimerization Model for Bacterial Persister Formation and Resuscitation. bioRxiv:663658 (2019).

17. Wood TK, Song S, \& Yamasaki R Ribosome dependence of persister cell formation and resuscitation. J. Microbiol. 57:DOI 10.1007/s12275-12019-18629-12272 (2019).

18. Cheverton Angela M, et al. A Salmonella Toxin Promotes Persister Formation through Acetylation of tRNA. Mol. Cell 63:86-96 (2016).

19. Kim J-S, Yamasaki R, Song S, Zhang W, \& Wood TK Single Cell Observations Show Persister Cells Wake Based on Ribosome Content. Environ. Microbiol. 20:2085-2098 (2018).

20. Yamasaki R, Song S, Benedik MJ, \& Wood TK Persister Cells Resuscitate Using Membrane Sensors that Activate Chemotaxis, Lower cAMP Levels, and Revive Ribosomes. bioRxiv doi 10.1101/486985:486985 (2019).

21. Aizenman E, Engelberg-Kulka H, \& Glaser G An Escherichia coli chromosomal "addiction module" regulated by guanosine 3',5'-bispyrophosphate: a model for programmed bacterial cell death. Proc Natl Acad Sci USA 93:6059-6063 (1996).

22. Bertani G Studies on Lysogenesis .1. The Mode of Phage Liberation by Lysogenic Escherichia-Coli. J. Bacteriol. 62:293-300 (1951).

23. Kwan BW, Valenta JA, Benedik MJ, \& Wood TK Arrested protein synthesis increases persister-like cell formation. Antimicrob. Agents Chemother. 57:1468-1473 (2013). 
24. Rodriguez RL \& Tait RC (1983) Recombinant DNA Techniques: An Introduction (Benjamin/Cummings Publishing, Menlo Park, CA).

25. Kitagawa M, et al. Complete set of ORF clones of Escherichia coli ASKA library (a complete set of E. coli K-12 ORF archive): unique resources for biological research. DNA Res 12:291-299 (2005).

26. Shah D, et al. Persisters: a distinct physiological state of E. coli. BMC Microbiol 6:53 (2006).

27. Song S, Gong T, Yamasaki R, Kim J-S, \& Wood TK Identification of a Potent Indigoid Persister Antimicrobial by Screening Dormant Cells. Biotechnol. Bioengr. https://doi.org/10.1002/bit.27078 (2019).

28. Cui P, et al. Identification of Genes Involved in Bacteriostatic Antibiotic-Induced Persister Formation. Front Microbiol 9:413 (2018).

29. Grassi L, et al. Generation of Persister Cells of Pseudomonas aeruginosa and Staphylococcus aureus by Chemical Treatment and Evaluation of Their Susceptibility to Membrane-Targeting Agents. Front Microbiol 8:1917 (2017).

30. Narayanaswamy VP, et al. Novel Glycopolymer Eradicates Antibiotic- and CCCP-Induced Persister Cells in Pseudomonas aeruginosa. Front Microbiol 9:1724 (2018).

31. Pu Y, et al. ATP-Dependent Dynamic Protein Aggregation Regulates Bacterial Dormancy Depth Critical for Antibiotic Tolerance. Molecular Cell 73:1-14 (2019).

32. Sulaiman JE, Hao C, \& Lam H Specific Enrichment and Proteomics Analysis of Escherichia coli Persisters from Rifampin Pretreatment. J Proteome Res 17:3984-3996 (2018).

33. Tkhilaishvili T, Lombardi L, Klatt A-B, Trampuz A, \& Di Luca M Bacteriophage Sb-1 enhances antibiotic activity against biofilm, degrades exopolysaccharide matrix and targets persisters of Staphylococcus aureus. Int J Antimicrob Agents 52:842-853 (2018).

34. Gutgsell NS, Deutsher MP, \& Ofengand J The pseudouridine synthase RluD is required for normal ribosome assembly and function in Escherichia coli. RNA 11:1141-1152 (2005).

35. Burger K, et al. Chemotherapeutic Drugs Inhibit Ribosome Biogenesis at Various Levels. J Biol Chem 285:12416-12425 (2010).

36. Lu T, Stroot PG, \& Oerther DB Reverse Transcription of 16S rRNA To Monitor RibosomeSynthesizing Bacterial Populations in the Environment. Appl Environ Microb 75:4589-4598 (2009).

37. Piques $\mathrm{M}$, et al. Ribosome and transcript copy numbers, polysome occupancy and enzyme dynamics in Arabidopsis. Mol Syst Biol 5:314 (2009).

38. Gogol EB, Rhodius VA, Papenfort K, Vogel J, \& Gross CA Small RNAs endow a transcriptional activator with essential repressor functions for single-tier control of a global stress regulon. Proc. Natl. Acad. Sci. U.S.A.:201109379 (2011).

39. Baba T, et al. Construction of Escherichia coli K-12 in-frame, single-gene knockout mutants: the Keio collection. Mol. Syst. Biol. 2:2006 0008 (2006).

40. Guyer MS, Reed RR, Steitz JA, \& Low KB Identification of a sex-factor-affinity site in E. coli as gamma delta. Cold Spring Harbor symposia on quantitative biology 45 Pt 1:135-140 (1981).

41. Hobbs EC, Astarita JL, \& Storz G Small RNAs and Small Proteins Involved in Resistance to Cell Envelope Stress and Acid Shock in Escherichia coli: Analysis of a Bar-Coded Mutant Collection. J. Bacteriol. 192:59-67 (2010). 
Table 1. E. coli bacterial strains and plasmids used in this study. $\mathrm{Km}^{\mathrm{R}}$ and $\mathrm{Cm}^{\mathrm{R}}$ indicate kanamycin and chloramphenicol resistance, respectively.

\begin{tabular}{lll}
\hline Strains and Plasmids & Features & Source \\
\hline BW25113 & Wild type & $(39)$ \\
BW25113 $\Delta r l u D$ & $\Delta r l u D \mathrm{Km}^{\mathrm{R}}$ & $(39)$ \\
MG1655 & Wild type & $(40)$ \\
MG1655 $\Delta r y b B$ & $\Delta r y b B \mathrm{Km}^{\mathrm{R}}$ & $(41)$ \\
MG1655 $\square \mathrm{ASV}$ & $r r n b \mathrm{P} 1:: \mathrm{GFP}[\mathrm{ASV}]$ & $(26)$ \\
Plasmids & & \\
pCA24N & $\mathrm{Cm}^{\mathrm{R}} ;$ lacl $^{q}$ & $(25)$ \\
pCA24N_rluD & $\mathrm{Cm}^{\mathrm{R}} ;$ lacl $^{q}, \mathrm{P}_{\mathrm{T} 5 \text {-lac }:: r l u D^{+}}$ & $(25)$ \\
\hline
\end{tabular}


Table 2. Compounds that resuscitate persister cells and their structures that were identified in the initial screen. Chemical structures are from ChemBridge. BPOET is indicated in bold.

\begin{tabular}{|c|c|}
\hline Name & Structure \\
\hline $\begin{array}{c}\text { 2-\{[2-(4-bromophenyl)- } \\
\text { 2-oxoethyl]thio\}-3- } \\
\text { ethyl-5,6,7,8- } \\
\text { tetrahydro[1]benzothie } \\
\text { no[2,3-d]pyrimidin- } \\
\text { 4(3H)-one (BPOET) }\end{array}$ & \\
\hline
\end{tabular}

$\mathrm{N}-[2-(3,4-$

dimethoxyphenyl)ethyl]-

$\mathrm{N}^{\prime}-[1-$

(pentafluorobenzyl)-1H-

pyrazol-3-yl]thiourea

(4-

methoxyphenyl)(phenyl) methanone

$$
\begin{aligned}
& \text { 6-(4-iodophenyl)-2- } \\
& \text { methylimidazo[2,1- } \\
& \text { b][1,3]thiazole }
\end{aligned}
$$

1-(2,4-dichlorobenzoyl)-

2,3-dihydro-1 H-

imidazo[1,2-

a]benzimidazole

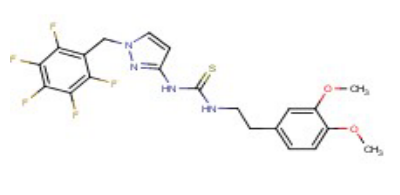<smiles>COc1ccc(C(=O)c2ccccc2)cc1</smiles>

2-methyl-4-[4-

(methylthio)phenyl]-5oxo-N-phenyl-

1,4,5,6,7,8-hexahydro-3quinolinecarboxamide

N-[4-(2-oxo-1-

pyrrolidinyl)phenyl]-1H-

1,2,4-triazole-3-

carboxamide<smiles>Cc1cn2cc(-c3ccc(I)cc3)nc2s1</smiles><smiles>O=C(c1ccc(Cl)cc1Cl)N1CCn2c1nc1ccccc12</smiles>

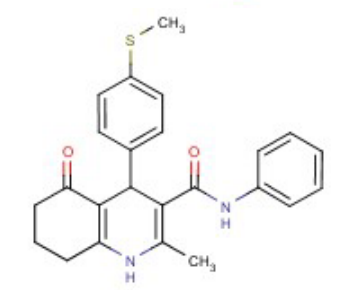

$\mathrm{N}$-(3-acetylphenyl)-4,5dimethyl-2-furamide

$\mathrm{N}-\{[(4-$

bromophenyl)amino]car

bonothioyl \}-2,2-

dimethylpropanamide

3-(3-chlorophenyl)-5,5dimethyl-4-methylene1,3-oxazolidin-2-one

4-

(isopropoxycarbonyl)ben zyl 2-

pyrazinecarboxylate

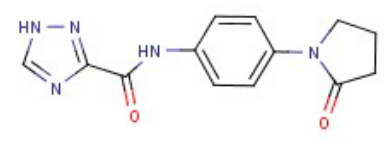

4-chloro-N-(4-oxo-1,4dihydro-2-

quinazolinyl)benzamide
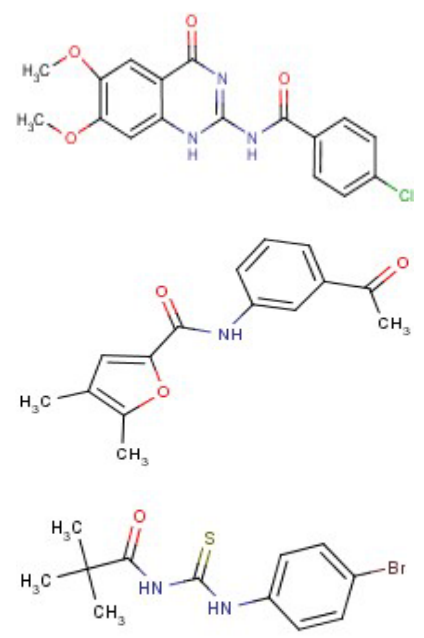<smiles>C=C1N(c2cccc(Cl)c2)C(=O)OC1(C)C</smiles><smiles>CC(C)OC(=O)c1ccc(COC(=O)c2cnccn2)cc1</smiles><smiles>O=C(Nc1nc(=O)c2ccccc2[nH]1)c1ccc(Cl)cc1</smiles> 
3-hydroxy-5-(4propoxyphenyl)-1-(3pyridinylmethyl)-4-(2thienylcarbonyl)-1,5dihydro-2H-pyrrol-2-one

\section{N'-[1-(3,4-} dimethoxyphenyl)ethylid ene]-3-phenyl-1H-

pyrazole-5carbohydrazide

N-(3-oxo-1,3-dihydro-2benzofuran-5-yl)-1H-

1,2,4-triazole-3carboxamide

$\mathrm{N}-(4-\{[(2,4-$ dimethoxyphenyl)amino ]sulfonyl \}phenyl)-3-[(4methylphenyl)thio]propa namide

N-(5-chloro-2methoxyphenyl)-N'-(1ethyl-3,5-dimethyl-1Hpyrazol-4-yl)thiourea

2,5-dichloro-N-(2furylmethyl)benzamide
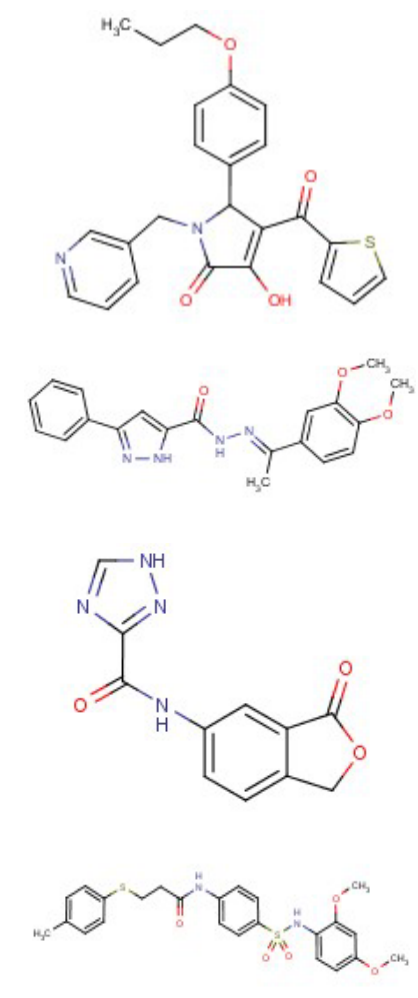<smiles>O=C(Nc1ccc2c(c1)C(=O)OC2)c1nc[nH]n1</smiles><smiles>CCn1nc(C)c(NC(=O)Nc2cc(Cl)ccc2OC)c1C</smiles><smiles>O=C(NCc1ccco1)c1cc(Cl)ccc1Cl</smiles>

5-(4-propoxybenzyl)1H-tetrazole
4-(3,4-

dimethoxyphenyl)-2-

hydrazino-6phenylpyrimidine

3-[4-(4-chlorophenyl)-1piperazinyl]-1-(4iodophenyl)-2,5pyrrolidinedione

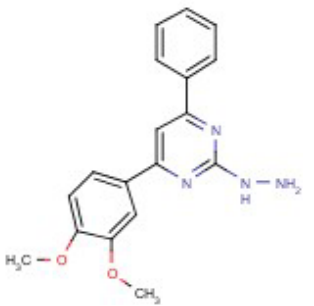

3-[(5-methyl-2furoyl)amino]benzoic acid<smiles>Cc1ccc(C(=O)Nc2cccc(C(=O)O)c2)o1</smiles>

$\mathrm{N} \sim 2 \sim-(3$-fluorophenyl)$\mathrm{N} \sim 2 \sim-($ methylsulfonyl)$\mathrm{N} \sim 1 \sim-[2-(1-$

pyrrolidinylcarbonyl)phe nyl]glycinamide<smiles>CS(=O)(=O)N(CC(=O)Nc1ccccc1C(=O)N1CCCC1)c1cccc(F)c1</smiles>

$1-[(4-$ methylphenyl)sulfonyl]N-1,3-thiazol-2ylprolinamide<smiles>Cc1ccc(S(=O)(=O)N2CCCC2C(=O)Nc2nccs2)cc1</smiles>

\section{$3-\{[(2-$}

methoxyphenyl)amino] methyl $\}-5-[4-$ (methylthio)benzylidene ]-1,3-thiazolidine-2,4-<smiles>COc1ccccc1CCN1C(=O)S/C(=C/c2ccc(O)cc2)C1=O</smilesdione

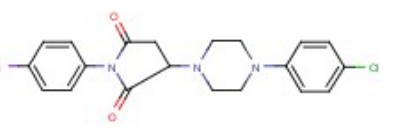<smiles>CCCOc1ccc(Cc2nnn[nH]2)cc1</smiles> 


\section{FIGURE LEGEND}

Fig. 1. RluD increases persister resuscitation by increasing ribosomes for resuscitation. (A) Singlecell persister resuscitation as determined using light microscopy (Zeiss Axio Scope.A1). The total and waking number of persister cells are shown in Table S1. Microscope images for waking cells are shown in Fig. S1. The fold-change in resuscitation is relative to BW25113 with DMSO for BW25113 with BPOET, relative to BW25113 for the $\triangle r l u D$ mutant, relative to BW25113/pCA24N for the strain producing RluD from pCA24N plasmid in BW25113, and relative to MG1655 for $\triangle r y b B$. M9 glucose $(0.4 \%)$ agarose gel pads were used for all the strains except BW25113 with BPOET where M9 alanine (5X) agarose gel pads including $100 \mu \mathrm{M}$ of BPOET or DMSO were used. The results are the combined observations from two independent experiments after $6 \mathrm{~h}$ for the BW25113 with BPOET, after $4 \mathrm{~h}$ for BW25113 and its deletion mutants, and after $6 \mathrm{~h}$ for cells harboring pCA24N and its derivatives as well as for MG1655 and MG1655 $\triangle r y b B$. Error bars indicate standard deviations. (B) Active 70S ribosomes in single persister cells for MG1655-ASV/pCA24N-rluD ("RluD") vs. MG1655-ASV/pCA24N ("Empty"). Cells are shown on agarose gel pads at time 0 for resuscitation; i.e., after the formation of persister cells. Representative results from three independent cultures are shown. 
(A)

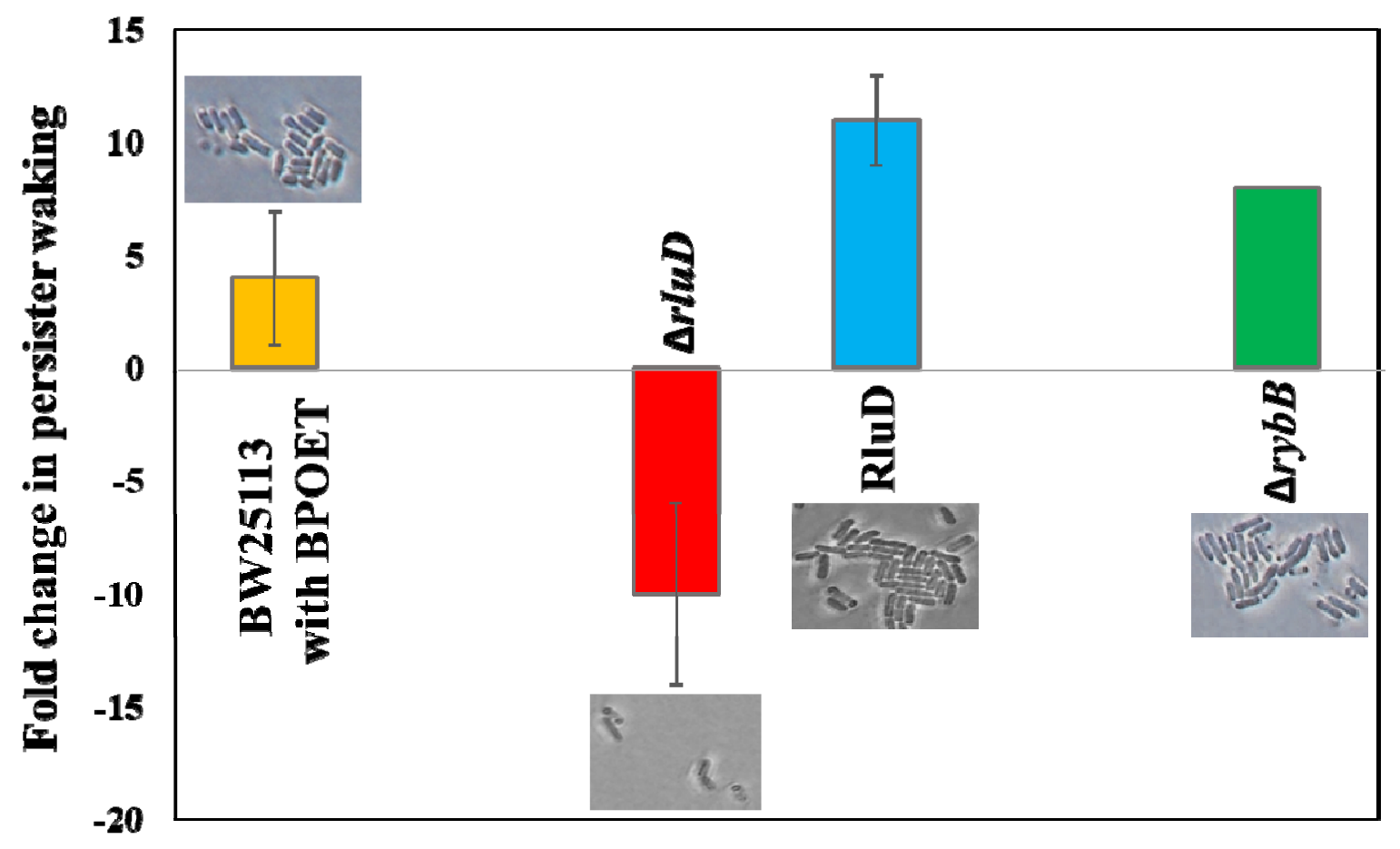

(B)

Empty

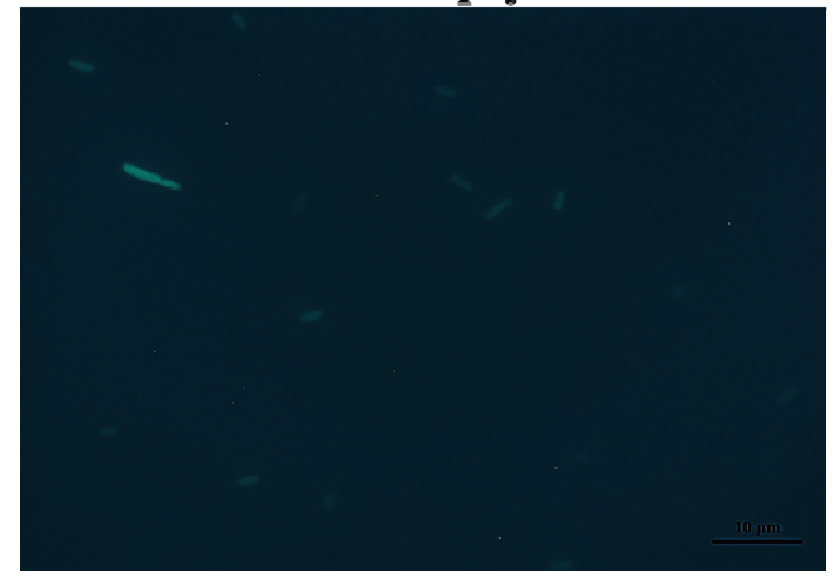

RluD

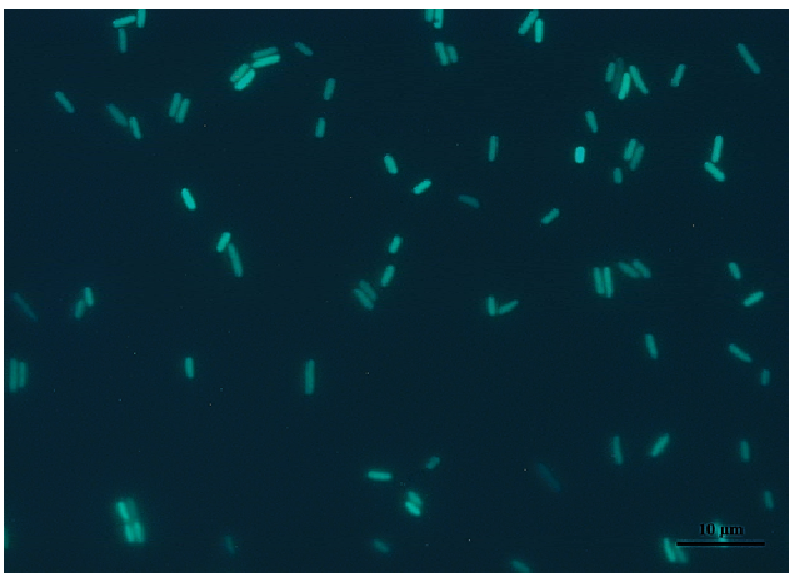

Figure 


\title{
SUPPORTING INFORMATION
}

\section{Persister Cells Resuscitate via Ribosome Modification by 23S rRNA Pseudouridine Synthase RluD}

\author{
Sooyeon Song and Thomas K. Wood* \\ Department of Chemical Engineering, Pennsylvania State University, \\ University Park, Pennsylvania, 16802-4400, USA
}

*For correspondence. E-mail tuw14@psu.edu

Tel. (+)1 814-863-4811; Fax (1) 814-865-7846

Running title: Persisters resuscitate via ribosome modification through RluD.

Keywords: persisters, indole 
Table S1. Single persister cell resuscitation. Single-cell persister resuscitation as determined using light microscopy (Zeiss Axio Scope.A1) using agarose gel pads. Microscope images are shown in Fig. S1. The fold-change in resuscitation is relative to BW25113 with DMSO for BW25113 with BPOET, relative to BW25113 for the $\triangle r l u D$, relative to BW25113/pCA24N for the strain producing RluD from pCA24N in BW25113, and relative to MG1655 for $\triangle r y b B$. M9 glucose $(0.4 \%)$ agarose gel pads were used for all the strains except BW25113 with BPOET where M9 alanine (5X) agarose gel pads including $100 \mu \mathrm{M}$ of BPOET or DMSO were used. The results are the combined observations from two independent experiments after $6 \mathrm{~h}$ for the BW25113 with BPOET and DMSO, after $4 \mathrm{~h}$ for BW25113 and its deletion mutants, and after $6 \mathrm{~h}$ for cells harboring pCA24N and its derivatives as well as for MG1655, and $\triangle r y b B$. Standard deviations are shown, and each strain was visualized at 14 positions.

\begin{tabular}{ccccc}
\hline & Total cells & Waking cells & \% waking & Fold-change \\
\hline BW25113 on DMSO & $215 \pm 46$ & $11 \pm 4$ & $5 \pm 2$ & 1 \\
BW25113 on BPOET & $213 \pm 49$ & $38 \pm 18$ & $20 \pm 13$ & $4 \pm 3$ \\
BW25113 & $150 \pm 46$ & $24 \pm 5$ & $16 \pm 1$ & 1 \\
$\Delta$ rluD & $327 \pm 16$ & $5 \pm 0$ & $1.5 \pm 0.1$ & $-10 \pm 1$ \\
& & & & \\
pCA24N & $233 \pm 155$ & $5 \pm 4$ & $1.8 \pm 0.3$ & 1 \\
pCA24N-rluD & $210 \pm 33$ & $43 \pm 6$ & $20 \pm 6$ & $11 \pm 4$ \\
& & & & 1 \\
MG1655 & $310 \pm 103$ & $8.5 \pm 5$ & $2.6 \pm 0.7$ & $8 \pm 2$ \\
\hline rybB & $208 \pm 10$ & $45 \pm 0$ & $22 \pm 1$ & \\
\hline
\end{tabular}


Table S2. Active 70S ribosomes in single persister cells for MG1655 $\square$ ASV/pCA24N-rluD ("pCA24N-rluD") vs. MG1655 $\square$ ASV/pCA24N ("pCA24N"). Single-cell persister resuscitation as determined using light microscopy (Zeiss Axio Scope.A1) using agarose gel pads with $0.4 \%$ glucose. Microscope images are shown in Fig. 1B. The fold-change in resuscitation is relative to MG1655 $\square \mathrm{ASV} / \mathrm{pCA} 24 \mathrm{~N}$ for MG1655 $\square \mathrm{ASV} / \mathrm{pCA} 24 \mathrm{~N}-\mathrm{rluD}$.

\begin{tabular}{lcc}
\hline & pCA24N-rluD & pCA24N \\
\hline Total cells & $140 \pm 66$ & $112 \pm 4$ \\
High intensity cells & $120 \pm 64$ & $25 \pm 3$ \\
Waking \% & $85 \pm 6$ & $22 \pm 2$ \\
Fold-change & $3.8 \pm 0.4$ & 1 \\
\hline
\end{tabular}


bioRxiv preprint doi: https://doi.org/10.1101/678425; this version posted June 21,2019 . The copyright holder for this preprint (which was not certified by peer review) is the author/funder, who has granted bioRxiv a license to display the preprint in perpetuity. It is made available under aCC-BY-NC-ND 4.0 International license.

(A)
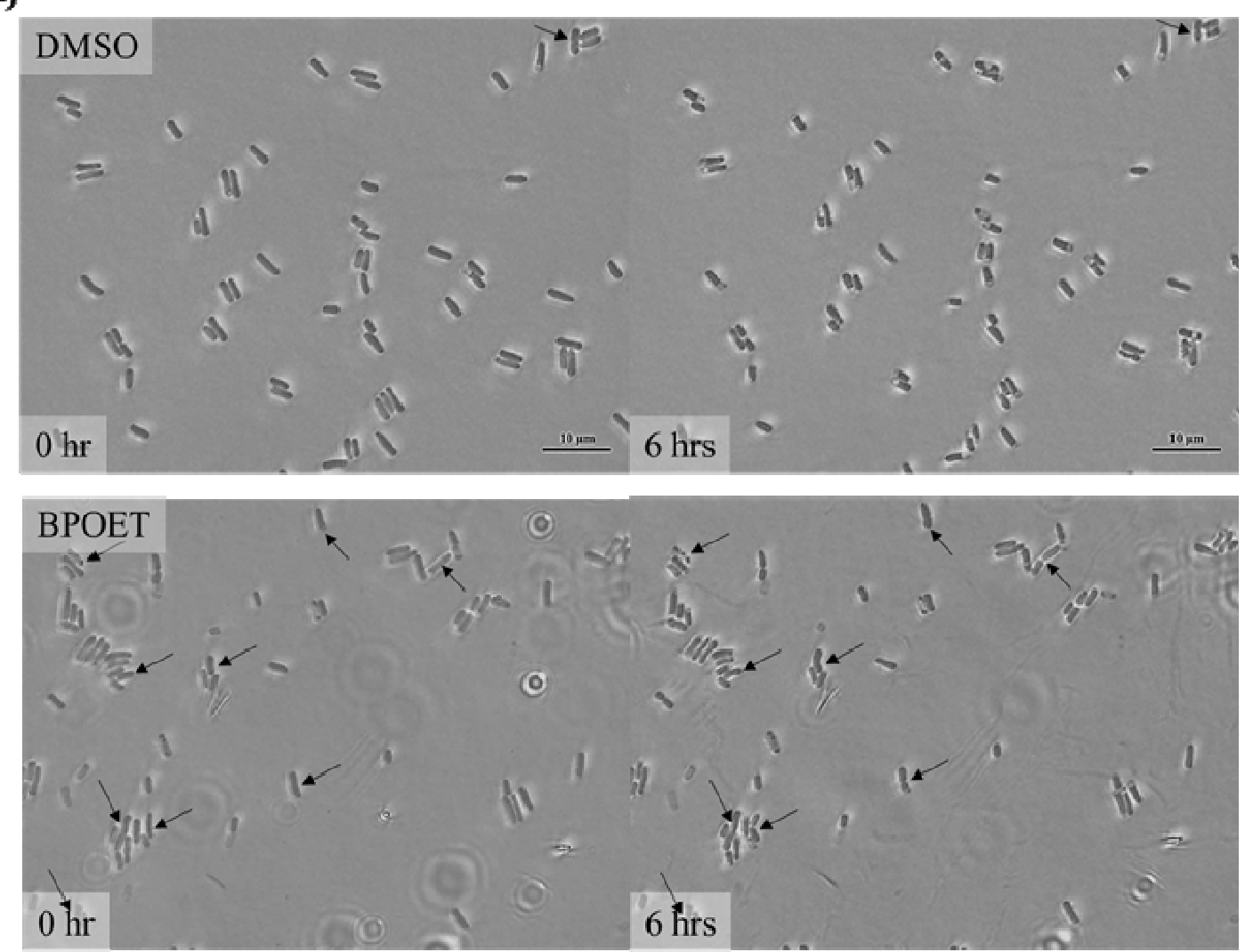

(B)
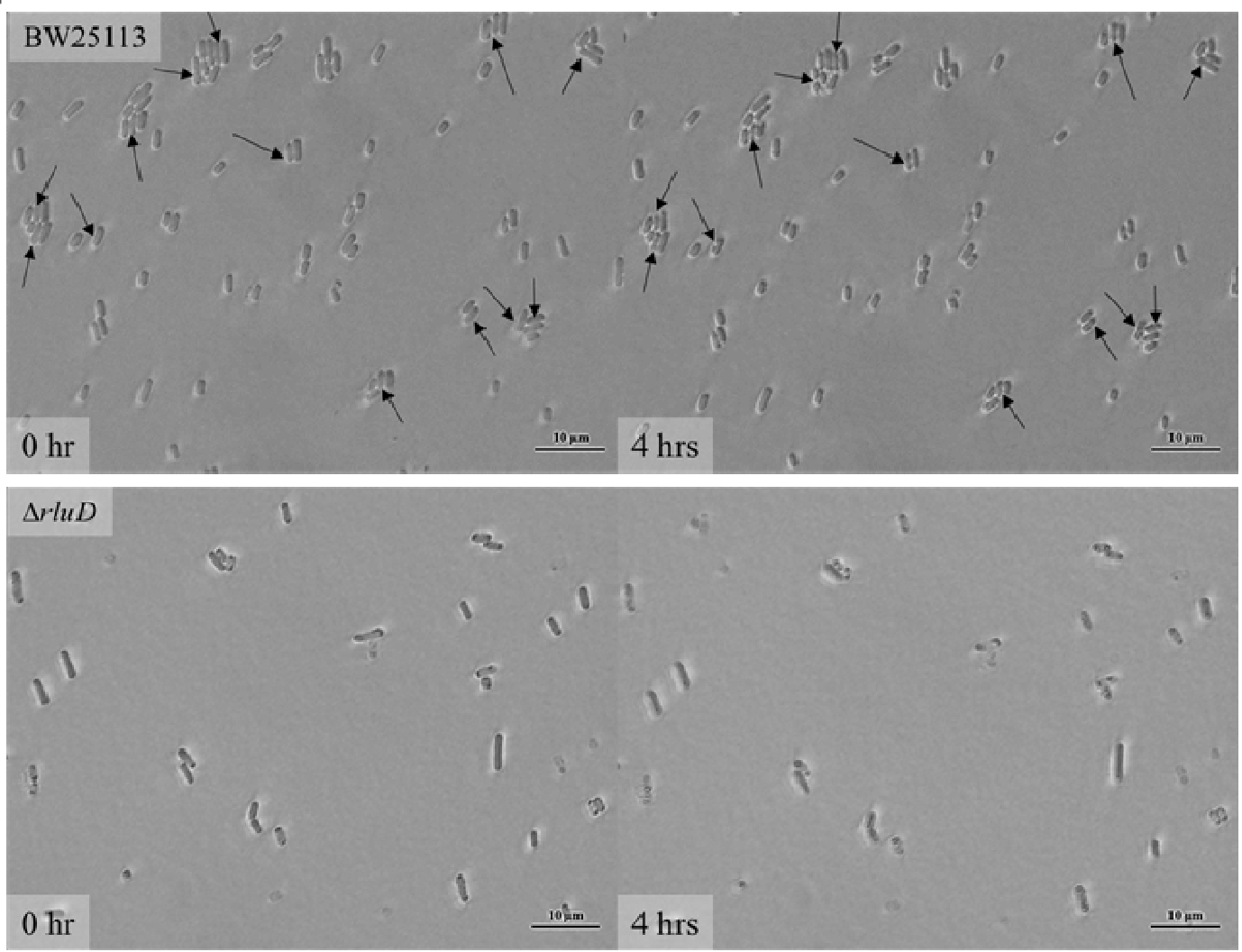


\section{(O)}
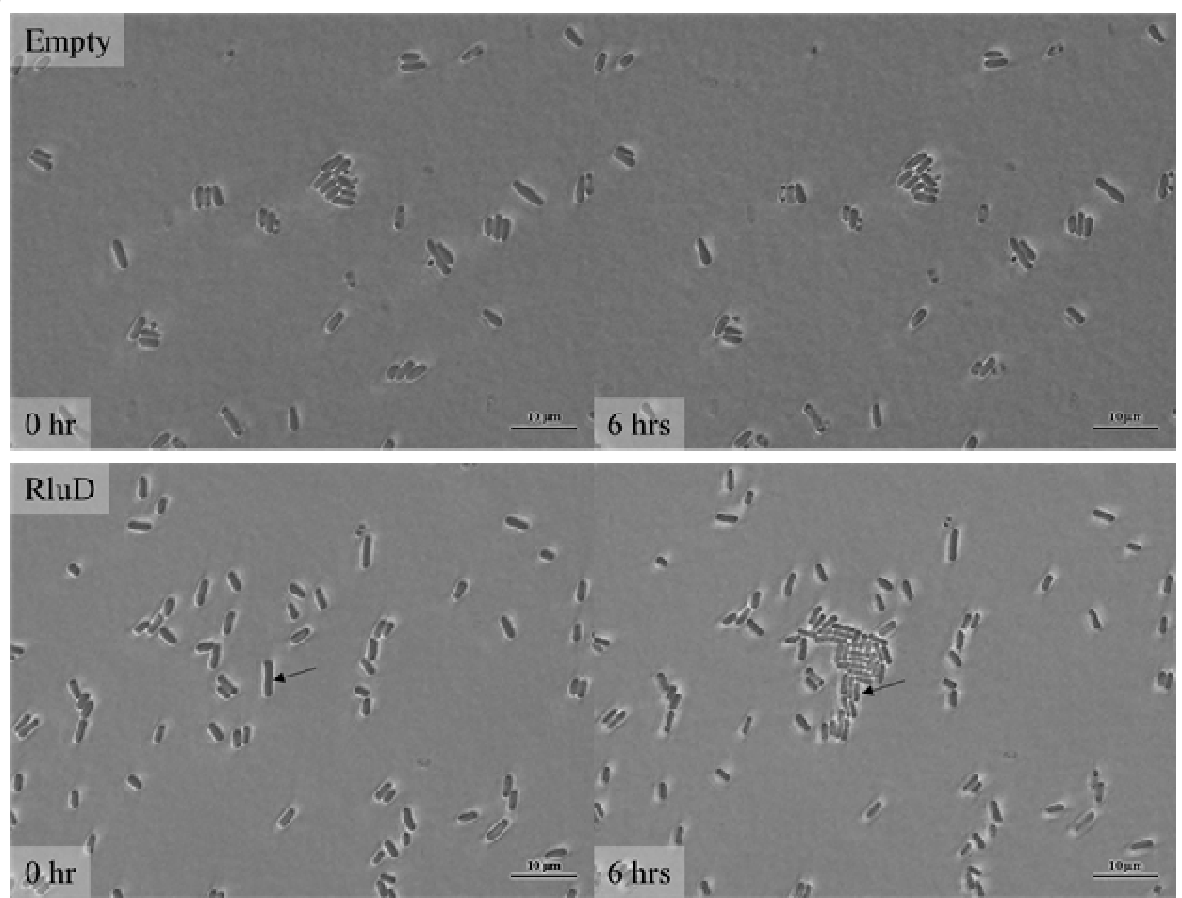

(D)
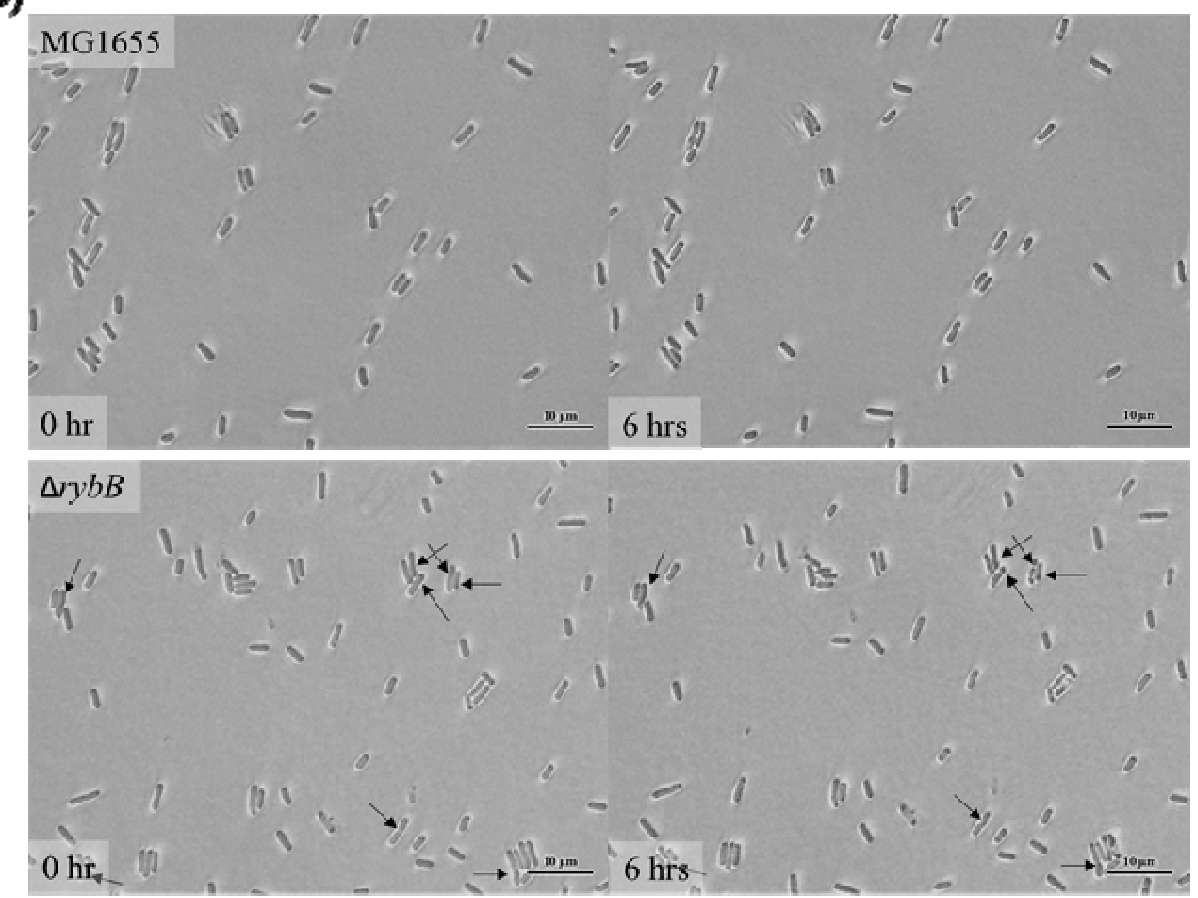

Figure S1. Single persister cell waking. Persister cells of (A) BW25113 with DMSO (upper panel), and BPOET (lower panel) on M9 5X Ala agarose gel pads containing DMSO and BPOET $(100 \mu \mathrm{M})$ after $6 \mathrm{~h}$, (B) BW25113 (upper panel) and BW25113 $\Delta r l u D$ (lower panel) after 4 hours on M9 $0.4 \%$ glucose agarose gel pads, (C) BW25113/pCA24N ("Empty"), and BW25113/pCA24N-rluD ("RluD") after 6 h on M9 $0.4 \%$ glucose agarose gel pads, and (D) MG1655, and MG1655 $\Delta r y b B$ after $6 \mathrm{~h}$ on M9 $0.4 \%$ glucose agarose gel pads. Black arrows indicate cells that resuscitate. Scale bar indicates $10 \mu \mathrm{m}$. Representative results from two independent cultures are shown. 
(A)

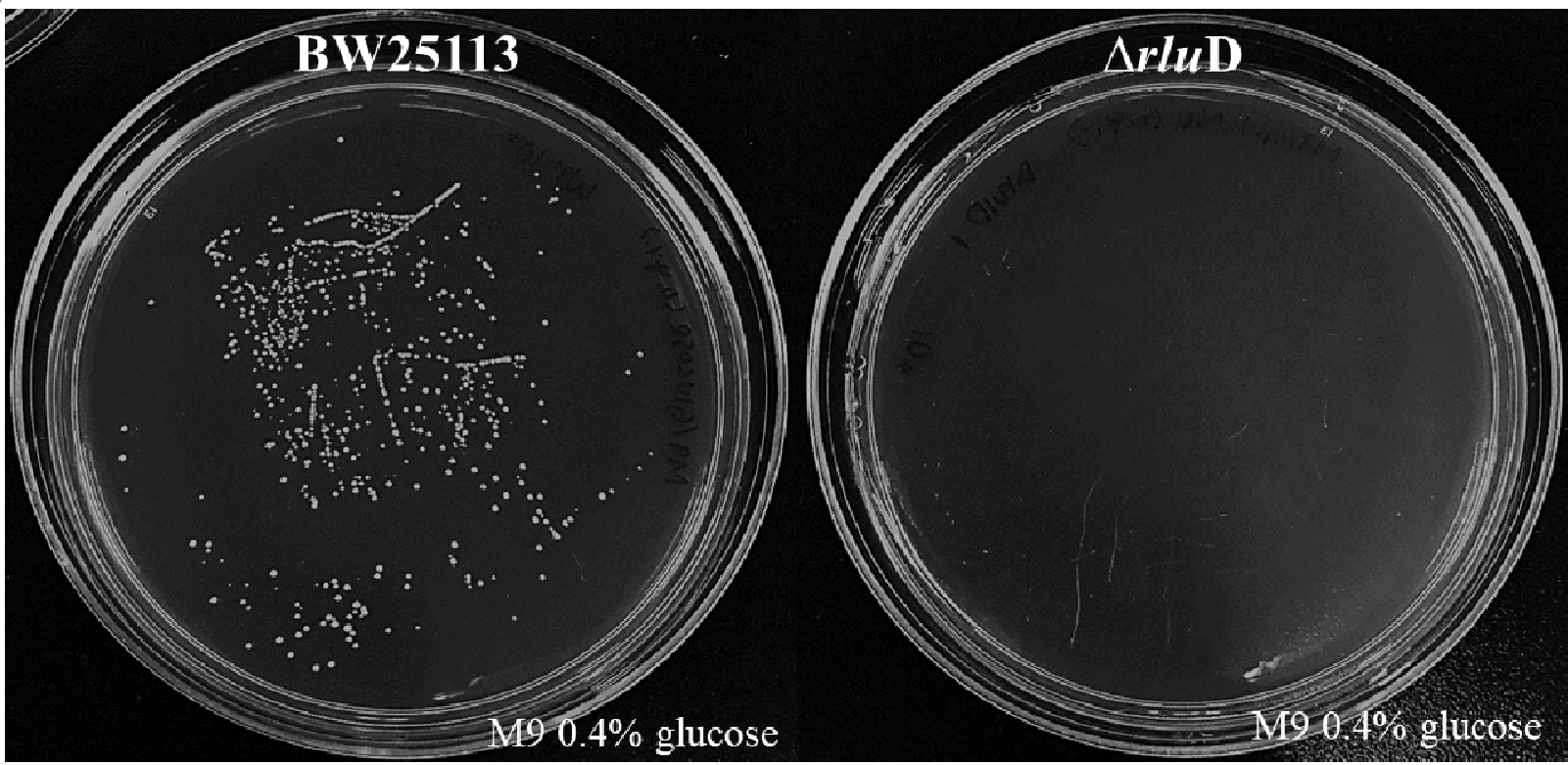

(B)

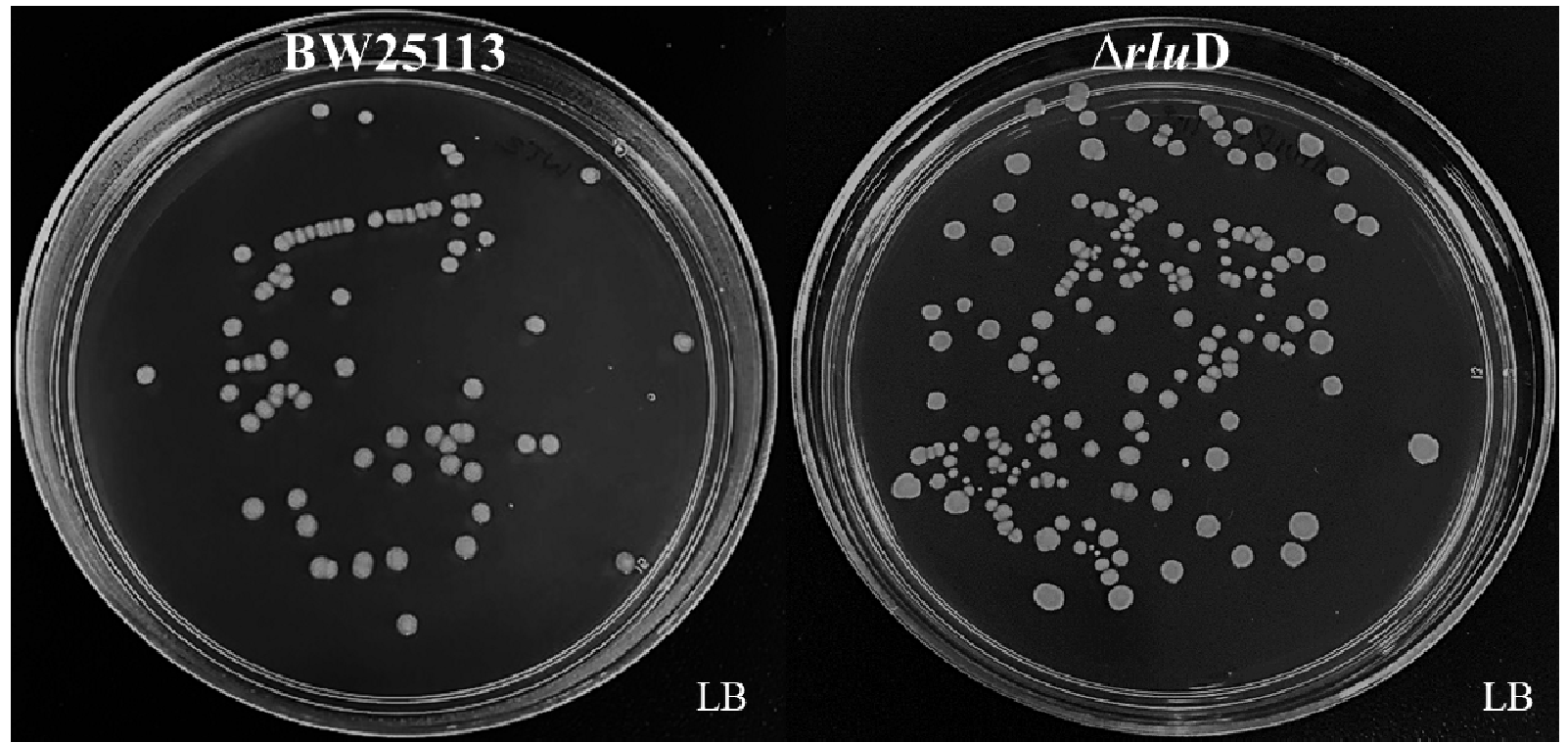

Figure S2. Inactivating RluD eliminates persister cell waking on minimal glucose medium but does not affect the number of persister cells that are formed. (A) Resuscitation of wild type BW25113 and BW25113 $\triangle r l u D$ persister cells at $37{ }^{\circ} \mathrm{C}$ on M9 $0.4 \%$ glucose agar plates for three days. (B) Colonies formed in one day at $37^{\circ} \mathrm{C}$ on LB agar plates indicating the number of persister cells for BW25113 and the isogenic $\triangle r l u D$ mutant. One representative plate of two independent cultures is shown. 